\title{
Discourses of Masculinity and Femininity in The Hunger Games: "Scarred," "Bloody," and "Stunning"
}

\author{
Vera Woloshyn ${ }^{1}$, Nancy Taber ${ }^{1}$, \& Laura Lane ${ }^{1}$ \\ ${ }^{1}$ Graduate and Undergraduate Studies in Education, Brock University, St. Catharines, Ontario \\ Correspondence: Vera Woloshyn, Graduate and Undergraduate Studies in Education, Brock University, St. \\ Catharines, Canada. Tel: 1-905-688-5550 ext 4212. E-mail: vwoloshyn@brocku.ca
}

Received: November 29, 2012 Accepted: December 12, 2012 Available online: February 28, 2013

doi:10.11114/ijsss.v1i1.21

URL: http://dx.doi.org/10.11114/ijsss.v1i1.21

\begin{abstract}
This article explores how characters in The Hunger Games trilogy are portrayed relative to Connell's gendered discourses of hegemonic masculinity, marginal masculinity, and emphasized femininity. We briefly review the plot of The Hunger Games trilogy and then discuss the ways in which three of the characters are represented with respect to societal gendered discourses, heteronormativity, and the use of violence. We argue that the ways in which these aspects are portrayed relate to the main characters' performance of discourses of hegemonic masculinity (Gale), marginalized masculinity (Peeta), and a complex amalgamation of the two that also draws somewhat on emphasized femininity (Katniss). Finally, we conclude that, while the trilogy could be read as taking a feminist stance with a strong female protagonist, it nonetheless also constrains Katniss in heteronormative ways.
\end{abstract}

Keywords: hegemonic masculinity, emphasized femininity, marginalized masculinity, children's literature, The Hunger Games

\section{Introduction}

This article explores how characters in The Hunger Games trilogy are portrayed relative to Connell's gendered discourses of hegemonic masculinity, marginal masculinity, and emphasized femininity. We briefly review the plot of The Hunger Games trilogy and then discuss the ways in which three of the characters are represented with respect to societal gendered discourses, heteronormativity, and the use of violence. We argue that the ways in which these aspects are portrayed are related to the main characters' performance of discourses of hegemonic masculinity (Gale), marginalized masculinity (Peeta), and a complex amalgamation of the two that draws somewhat on emphasized femininity (Katniss). We conclude that, while the trilogy could be read as taking a feminist stance with a strong female protagonist, it also constrains Katniss in heteronormative ways.

\subsection{Exploring Connell's Notions of Gender Practice as Relates to Children's and Young Adult Literature}

Although examples of "reversal, contrast, and struggle" (Tolmie, 2006, p. 146) are present in all forms of literature, particularly with respect to the agency of female characters, females are still too often represented in traditional ways that focus on their domestic roles, appearance, and subservience while male characters are presented as masculine active heroes, corresponding to Connell's (1987, 2005, 2012; see also, Connell \& Messerschmidt, 2005) descriptions of emphasized femininity and hegemonic masculinity, respectively. Although girls may at times be shown to engage in active roles, their femininity too often continues to define them (Taber \& Woloshyn, 2011b, Diekman \& Murnen, 2004, Jackson \& Gee, 2005). For instance, young women in fairy tales typically have been portrayed as beautiful passive victims who need to be rescued by strong males from ugly evil crones (Bacchilega, 1997; Baker-Sperry \& Grauerholz, 2003; Parsons, 2004; Trousdale \& McMillan, 2003; for discussion of associated complexities see Haase, 2004; Harries, 2001). Heterosexist representations such as these are found in genres as diverse as diary cartoon novels (Taber \& Woloshyn, 2011a), horror fiction (Heinecken, 2011), fantastical realism (Waller, 2004), novels about sisterhood (McInally, 2008), and award winning literature (Taber \& Woloshyn, 2011b). While characters sometimes may appear to challenge the notions of emphasized femininity and hegemonic masculinity, heteronormative gendered norms usually are upheld for boys (Chaudri, 2011; Pugh \& Wallace, 2008; Wannamaker, 2006) and girls (Taber \& Woloshyn, 2011a; Taber \& Woloshyn, 2011b; Hager, 2003; McInally, 2008). 


\subsection{Emphasized Femininity}

Many female characters, who initially may appear to be strong role models, often remain constrained by patriarchal norms of emphasized femininity in that they eventually are returned to traditional roles, "safely brought back to orthodox femininity" (Dominguez-Rue, 2010, p. 306), constructed as virgins in need of rescue (Baecker, 2007), domestics (Waller, 2004), wives and mothers (Pérez Valverde, 2009). Alternatively, if they refuse to conform, they are often represented as "outsiders" (Pérez Valverde, 2009, p. 264), "monstrous" (Heinecken, 2011, p. 129), "too- powerful" (Parsons, Sawars, \& McInally, 2008, p. 371), or "bad" (Bird, 1998, p. 122). While these female characters may be viewed as role models, they also can serve as cautionary tales; girls and women who contest heteronormativity may do so at their own risk. Despite the complex ways in which women navigate their own lives in reality, in children's literature, they are too often "divided with the designation of 'good' or 'evil"' (Parsons, 2004, p. 137), "benefactor...or... harmful, menacing presence" (Pérez Valverde, 2009, p. 264), where good benefactors are consonant with emphasized femininity and evil "demonizing" (Parsons et al., 2008, p. 317) presences are consonant with those who refuse to conform.

\subsection{Hegemonic and Marginalized Masculinities}

Male protagonists, in contrast, often enact aspects of hegemonic masculinity, which encompasses cultural, temporal, and geospatial "configurations of practice" (Connell, 2005), wherein, in patriarchal societies, "the majority of men gain...from the overall subordination of women" (p. 79). Although there are multiple ways in which men demonstrate various versions of masculinity, hegemonic masculine practices typically are privileged in that they present men as strong protectors and leaders who deserve to be in positions of authority over women and marginalized men. "Marginalized masculinities" (Connell, 2005) are present in fiction, with male characters who enact these types of masculinities typically represented as subordinate to those who enact hegemonic masculinities and the ideal of heteronormativity (Chaudri, 2011; Pugh \& Wallace, 2008; Wannamaker, 2006). Collectively, these representations of emphasized femininity, hegemonic masculinity, and marginalized masculinities describe contending complexities versus opposing binaries as "configurations of practice generated in particular situations in a changing structure of relationships" (Connell, 2005, p. 81). These performances of gender occur in everyday life just as they do in fiction.

\section{Methodology}

In this article, we applied a feminist discourse analysis (Lazer, 2005) to critique the ways in which gender was enacted through the characters of Katniss, Peeta, and Gale as presented in The Hunger Games trilogy. Feminist discourse analysis "examine[s] how power and dominance are discursively produced and/or resisted in a variety of ways through textual representations of gendered social practices, and through interactional strategies of talk" (Lazar, 2005, p. 10). Consistent with Gee's (2005) recommendation of modifying discourse analysis methods in order to negotiate between research objectives, text structure, and genre, we employed Glaser and Strauss' (1967) constant comparative method. We read each novel in the trilogy independently to identify emerging gendered discourses. We then met to review these discourses, identifying common themes and exploring how they mapped onto Connell's representations of emphasized femininity, hegemonic masculinity, and marginalized masculinities. We discuss these themes in context of how "gender ideology and gendered relations of power are (re)produced, negotiated and contested" (Lazar, 2005, p. 11) below.

\section{Trilogy Overview}

The Hunger Games series is a young adult dystopian science-fiction series comprised of three books by Suzanne Collins: The Hunger Games (2008), Catching Fire (2009), and Mockingjay (2010) which are narrated in first person by the female protagonist, Katniss Everdeen, and set in a dystopian future of North America since renamed Panem. Panem is divided into 13 districts and governed by the wealthy Capitol, lead by President Snow. To punish the districts for a lost rebellion, reinforce the power of the Capitol, and entertain its citizens, a boy and a girl from each district are selected randomly to participate in the annual games where they fight to the death in a televised arena. The sole survivor is proclaimed victor and is afforded a life of relative luxury upon returning home, with food and other resources also being allocated to his or her district for the remainder of the year. The first book focuses on Katniss' survival in the arena, after volunteering to take her sister Prim's place in the Games. The later books focus on her resistance to the totalitarian leaders President Snow and President Coin (leader of supposedly deserted District 13). Her relationships with her younger sister Prim, best friend Gale, co-tribute Peeta, mentor Haymitch, and absent mother are discussed throughout.

\section{Gendered Characters: Masculinities and Femininities}

Throughout the Hunger Games trilogy, two of the male characters are placed in relative juxtaposition to each 
other through their performances of masculinity that relate most to hegemonic masculinity (Gale) and marginalized masculinity (Peeta). Katniss' character is represented as possessing masculine and feminine characteristics; her female body marks her as a woman with elements of emphasized femininity while her actions encompass elements of hegemonic masculinity. These characteristics emerge at different junctures throughout the books, with the tendency towards a demonstration of more emphasized femininity as the narrative progresses. The characters' "body-reflexive practices...constitute a world which has a bodily dimension, but is not biologically determined" (Connell, 2005, p. 65). As such, Gale, Peeta, and Katniss are not bound by their bodies, but their "bodily performance" (p. 54) interacts with the gendered social practices of not only the fictional Panem, but also western society. We explore the ways in which forms of masculinity and femininity are represented in Gale, Peeta, and Katniss.

\subsection{Gale: Hegemonic Masculinity}

\subsubsection{Discourse of Protection}

The character of Gale (as with all the characters in the trilogy) is viewed through the eyes of Katniss. Katniss has a close relationship with Gale, having spent many hours hunting with him. She is most familiar with his actions in this context, leading her to associate him with characteristics most consistent with a contemporary western form of hegemonic masculinity. "'Hegemonic masculinity' is not a fixed character type, always and everywhere the same. It is, rather, the masculinity that occupies the hegemonic position in a given pattern of gender relations, a position always contestable" (Connell, 2005, p. 76). In District 12, men are expected to provide for and protect their families, as well as be desirable to women. Gale fits this position well, with Katniss describing him as a strong, capable, decisive, and independent young man who provides for his mother and siblings as well as others in the community. As an eligible bachelor, he has gained the attention of many young women. Katniss states:

if he wants kids, Gale won't have any trouble finding a wife. He's good-looking, he's strong enough to handle the work in the mines, and he can hunt. You can tell by the way the girls whisper about him when he walks by in school that they want him (The Hunger Games, p. 10).

Gale maintains a familial leadership role by keeping his promise to Katniss to protect and support their families forgoing the opportunity to escape from his district, eventually assuming a critical role in plotting against the Capitol and encouraging rebellion and retaliation. He tells Katniss, "we have to join the fight" (Catching Fire, p. 100), when she wants to run away with him, Peeta, and their families. Gale asks, "'What about the other families, Katniss? The ones who can't run away? Don't you see? It can't be about just saving us anymore"' (Catching Fire, p. 100). Through his concern for family and community, Gale demonstrates that he is caring and committed to relationships. However, these characteristics do not challenge his enactment of hegemonic masculinity but enhance it, with this caring framed through a reliance on strength and violence. As Messner (2007) argues with respect to adaptive forms of masculinity, "toughness, decisiveness, and hardness are still central to hegemonic masculinity, but it is now normally linked with situationally appropriate moments of compassion and, sometimes, vulnerability" (p. 466).

\subsubsection{Discourse of War}

Gale's character as presented by Katniss remains resolute as the trilogy progresses and he emerges as a warrior, military strategist, and weapons expert. He is willing to sacrifice himself for what he considers to be a greater cause, to regain power and autonomy from the Capitol, and is represented as an authoritative figure, holding high rank in District 13. He is persistent in his orientation that might is right, can be relied on to make tough decisions, and believes that violence and manipulation are justified means by which the districts can regain autonomy. He somewhat reluctantly accepts the suffering and death of innocents (including children) as collateral damage, explaining that he "would sacrifice a few [innocents], yes, to take out the rest of them" (Mockingjay, p. 205). Gale is rewarded for his unwavering commitment to the rebellion and his leadership in the uprising. At the end of the rebellion he is awarded a "fancy job" where he is seen "now and again on the television" (p. 384); he has moved beyond those who remain in District 12, "probably kissing another pair of lips" (Mockingjay, p. 385). Gale is steadfast, persevering, and heroic, represented as admirable in his hegemonic masculinity wherein he "gain[s] a dividend from patriarchy in terms of honour, prestige and the right to command" (Connell, 2005, p. 82).

The ways in which Gale enacts masculinity move on a spectrum from hegemonic to hypermasculine. As he participates in violent activities he increasingly becomes disconnected from any traits related to caring and nurturing. As in other novels, his character "devalues the feminine as something 'other' that must be overcome in order to mature, in order to become human" (Wannamaker, p. 24). It is only by being hypermasculine that he believes he can protect those from his district, as he "correlat[es] masculinity with physical endurance, 
aggression, stoicism" (Hockey, 2003, p. 18) and survival.

\subsection{Peeta: Marginalized Masculinity}

\subsubsection{Discourses of Inadequacy}

Peeta is most often represented as possessing marginalized masculine characteristics, which are contrasted frequently with Gale's hegemonically masculine ones. At the start of the series, Peeta is described by Katniss as somewhat attractive, with "medium height, stocky build, ashy blond hair that falls in waves over his forehead" (The Hunger Games, p. 25), but also as weak, unskilled, naive, and privileged as the baker's son who has "always had enough" (The Hunger Games, p. 292). Katniss states, "It's not that Peeta's soft exactly, and he's proved he's not a coward. But there are things you don't question too much, I guess, when your home always smells like baking bread, whereas Gale questions everything" (The Hunger Games, p. 296). Again, various types of masculinity are viewed as hegemonic in specific contexts. For example, Connell (2005) contrasts working-class blue-collar masculinity with middle-class white-collar masculinity. In the context of District 12, hegemonic masculinity is enacted by tough men who are take care of themselves and others by virtue of their strength. While Gale becomes a miner, Peeta remains the baker's son. This "gender politics" (Connell, 2005, p. 37) positions Gale as a better ally than Peeta, both inside and out of the Games.

Peeta is not expected to do well in the Games, with he himself stating that, "'I've never been a contender"' (The Hunger Games, p. 141) and telling Katniss, "'You know what my mother said to me when she came to say good-bye, as if to cheer me up, she says maybe their district will finally have a winner. Then I realized, she didn't mean me, she meant you!'" (The Hunger Games, p. 90). Peeta is concerned, however, that he remain true to his convictions, beliefs, and character and appears able to do so throughout the trilogy. He wants to "'die as myself...I don't want them to change me in there. Turn me into some kind of monster that I'm not"' (The Hunger Games, p. 141). As such, he shows an admirable strength of character that, relatively, is useless in context of the Games.

Peeta expresses his love for Katniss in a televised interview before the Games, implementing a plan to endear her to potential sponsors and the citizens of the Capitol. His caring and attempt to protect is very different from Gale's, as he does not use toughness and violence but cleverness and wit. When he teams up with the Careers in an attempt to draw them away from Katniss, Peeta portrays himself as willing to fight and kill, which is not borne out by his actions. In these ways, Peeta's enactment of marginalized masculinity seems worthy of respect. Indeed, Connell (2005) herself recognizes that the word marginalized is not entirely accurate, but is the closest she could find to describe the relations of "alliance, dominance, and subordination" (p. 37) among masculinities.

Nonetheless, Peeta is portrayed as less than Gale in context of the Games, possessing few hunting, fighting or other survival skills. He is capable at camouflage which, although useful, has seemingly little relative value compared to hunting or fighting. Furthermore, his skill is feminized when Katniss attributes it to icing cakes stating, "I guess all those hours decorating cakes paid off" (The Hunger Games, p. 252). When Katniss is reunited with Peeta during the first Games she considers him to be a burden with little to offer to her survival. Katniss compares Peeta to Gale explaining, "even on a smooth bed of needles, Peeta is loud. And I mean loud loud, as if he's stomping his feet or something" while Gale is the exact opposite, with a "velvet tread" (The Hunger Games, p. 314, italics in original).

\subsubsection{Discourses of Peace and Altruism}

Throughout the remaining two books, Peeta again is presented as an individual who is committed to peace and is loyal to those he loves. He also is represented as a victim and someone who is physically weaker than others, a key aspect of marginalized masculinity (Connell, 2005, 2012). He does not intentionally harm others but adopts a defensive orientation towards protecting Katniss and himself. Furthermore, he objects to Gale's military operations during the rebellion, and speaks against undue violence and the harming of innocents, being viewed as a traitor for doing so.

"I am calling for a cease-fire," says Peeta tiredly....

Behind me, I [Katniss] can hear the accusations against Peeta building. The words traitor, liar, and enemy bounce off the walls (Mockingjay, pp. 26-27 italics in original).

Gale, in contrast, is willing to engage in violence when required. As such, Peeta's masculinity is marginalized in relation to those who have joined with and fight for the rebels, with Gale claiming his "right to command" (Connell, 2005, p. 83) and Peeta being ostracized. District 13 is run in ways very similar to military organizations, with citizens expected to acquiesce to hierarchical control, conduct drills, and fight when necessary. As "violence on the largest possible scale is the purpose of the military" which is "important for the 
definition of hegemonic masculinity" (Connell, 2005, p. 213), Peeta's masculinity is not only marginalized but maligned.

In the epilogue Peeta continues his struggle against the brainwashing he endured while a prisoner of the Capitol by consciously and effortfully extending his trust to Katniss, highlighting the caring aspects of his character as well as recognizing a changed Peeta who is more capable of distrust and violence. Perhaps the gaining of some traits that are more consistent with hegemonic notions of masculinity make him more attractive to Katniss, who ultimately decides to remain with him, creating a heteronormative nuclear family. Katniss states:

Peeta and I grow back together. There are still moments when he clutches the back of a chair and hangs on until the flashbacks are over. I wake screaming from nightmares of mutts and lost children. But his arms are there to comfort me. And eventually his lips. (Mockingjay, p. 388)

This plotline could be viewed as an example of how literature often demonstrates that "brutal transformations into manhood not only reinforce our culture's need to put boys through physical trials, but also work to reinforce stigmas against boys who have feminine traits" (Wannamaker, 2006, p. 23).

Collectively, Peeta's character is best defined through the feminine characteristics of peace, loyalty, love, and altruism. He is represented as a character of high moral standing and personal integrity. While it could be argued that Peeta's character is a positive example of a marginalized masculinity (or one that is not hegemonic as represented by Gale), Peeta's feminine characteristics in a male body establish him as weak and in need of protection. Peeta has a "purity of self" (The Hunger Games, p. 142) that is to be admired, but his idealism is portrayed as having no place in their dystopia. His "alternative mod[e] of masculinity" (Chaudhri, 2011, p. 159), is therefore marginalized (Connell, 2005), particularly with respect to his struggle with violence (which he arguably overcomes but continues to live with) that changes his character in the final book. Finally, the ending wherein Katniss marries Peeta demonstrates how, "The utopian image of the happy heterosexual union that appears at the conclusion of traditional romance novels is one that draws upon dominant discourses of gender and sexuality and serves to normalize and reinforce the acceptability of heterosexuality" (Pattee, 2008, p. 156) and hegemonic masculinity.

\subsection{Katniss: A Complex Amalgamation}

\subsubsection{Discourse of the Involuntary Protector}

Katniss demonstrates a complex mix of masculine and feminine characteristics, as illustrated by her similarities and differences with Gale and Peeta. Unlike Gale, who is represented as a strong masculine protector, and Peeta, who is good but weak, Katniss is represented, in her own voice, as imperfect, despite her ability to protect and fight. At the beginning of the trilogy, Katniss is presented as possessing many hegemonically masculine attributes. She is independent, unafraid, and skilled. She cares for her sister and is critical of her mother who is unable to function after her husband's death. Although Katniss recognizes that her mother is suffering from depression, she resents her weakness and is skeptical of her ability to care for her sister. "I suppose now that my mother was locked in some dark world of sadness, but at the time, all I knew was that I had lost not only a father, but a mother as well" (The Hunger Games, p. 27).

Katniss is an example of Taber and Woloshyn's (2011b) argument that, while female characters may take on masculine tasks and roles, they often only do so in exceptional circumstances usually involving the absence of a father figure, reinforcing the idea that this behaviour is not normative. Katniss decries the uselessness of her mother, mirroring Gale's position as head of a family. "They're not our kids, of course. But they might as well be. Gale's two little brothers and a sister. Prim. And you may as well throw in our mothers, too, because how would they live without us?" (The Hunger Games, p. 9). As Katniss leaves for the arena, she shouts at her mother, "'You can't clock out and leave Prim on her own. There's no me now to keep you both alive"' (The Hunger Games, p. 35). She then garners promises from Gale as well as Peeta's father to care for them, selecting two male characters to replace her role as family provider, further propping up familial "patriarchal power" (Connell, 2005, p. 74). Katniss' disconnect with her mother continues throughout the series, with this pattern of mother-inability and abandonment repeated after Prim's death and Katniss finally realizing, "'My mother's not coming back"' (Mockingjay, p. 379).

Unlike Gale however, her caring increasingly becomes attached to emphasized femininity, as opposed to Gale's hegemonic masculinity. Katniss's relationship with Prim is paralleled to her bond with Rue in the Games, which she reciprocates only after Rue assists her in escaping from the Careers. "Since she tipped me off, it only seems fair to warn her" (The Hunger Games, p. 184). Katniss protects Rue, mourning her eventual death by covering her in flowers in defiance of the game-makers. Her relationship with Rue is very sisterly, taking on aspects of 
mothering, perhaps preparing readers for her eventual return to the home at the end of the trilogy.

\subsubsection{Discourses of Uninvited Attention and Romance}

Katniss's appearance as a heteronormative object of desire is very important in the trilogy, with how she looks and is desired often viewed as more important than who she is. As she begins the Hunger Games, Katniss is forced to assume characteristics related to feminine beauty ideals (Baker-Sperry \& Grauerholz 2003; Wolf, 2002). Baker-Sperry and Grauerholz (2003) argue that stories "convey messages about the importance of feminine beauty not only by making 'beauties' prominent...but also in demonstrating how beauty gets its rewards" (p. 722). In the case of The Hunger Games, although Katniss resists a focus on her appearance, it is made very clear that, in order to gain support from sponsors who can provide life-saving resources in the Games, Katniss has to look beautiful and feminine at the same time as she needs to refuse emotions that would mark her as weak. These necessities provide an informative example of the interactions between hegemonic masculinity and emphasized femininity in Katniss' character due to the context of the Games. Conceivably, if she had been able to stay out of the Games, there would have been no need for her to attend to her appearance in ways that would reinforce emphasized femininity, "'We don't have much cause to look nice in District 12"' (The Hunger Games, p. 62).

Katniss credits Peeta as making her desirable and interesting through his proclamation of love, despite being subjected to the efforts of her prep team and stylist, who claim that after much work cleaning her up "'You almost look like a human being now"' (The Hunger Games, p. 62), which seems to be code for human female. Katniss explains that without Peeta, she was just "silly and sparkly and forgettable" (The Hunger Games, p. 136) and, only by virtue of the efforts of others, is worthy of sponsor support. "And there I am, blushing and confused, made beautiful by Cinna's hands, desirable by Peeta's confession, tragic by circumstance, and by all accounts, unforgettable" (The Hunger Games, p. 138). As such, both Katniss and Peeta are bound by "compulsory heterosexuality" (Butler, 1999; Connell, 2005) although it is Katniss, not Peeta, who is improved by the romance.

In the third book, the rebellion leaders also find Katniss' appearance lacking and rely on the efforts of her prep team to portray her as the ideal rebel leader. In doing so, they strive to make her look like a realistic fighter while emphasizing her attractiveness, another connection between hegemonic masculinity (tough, able protector) and emphasized femininity (appealing, alluring). She is to be "'scarred and bloody"' yet "'stunning"' (The Mockingjay, p. 44) as a member of her prep team asks, "'Just how grimy can we make her without disgusting people?"' (p. 44). Katniss expresses surprise that her appearance remains important even when she is no longer a tribute. "As a rebel, I thought I'd get to look more like myself. But it seems a televised rebel has her own standards to live up to" (Mockingjay, p. 60). Katniss realizes the fakeness and constructedness of her appearance as she describes how she is made to be alternatively "breathtaking" (The Hunger Games, p. 70), "Innocent. Harmless" (The Hunger Games, p. 355), "deadly" (Catching Fire, p. 207), "stunning" (Mockingjay, p. 44), and "sexy" (Mockingjay, p. 70), depending on the context. Katniss' hegemonically masculine traits (including appearance and actions) are gradually waxed off, washed away, and covered up so that she can become more "human" (The Hunger Games, p. 62) (or, properly feminine) and represent the appropriate type of femininity for social acceptance and viewer support. In this way, "gender inequality is reproduced" (Baker-Sperry \& Grauerholz 2003, p. 723) through the various representations of Katniss that are determined by others, including Peeta, Haymitch, President Coin, and the Capitol. Appearance and attraction are central in The Hunger Games just as in other children's and young adult literature (Taber \& Woloshyn, 2011a; McInally, 2008).

\subsubsection{Discourses of Manipulation, Unworthiness, and Domesticity}

In the first two books, Katniss also presents herself as relatively naive compared to others with respect to using the media to gain and manipulate viewers' opinions. Her emphasized femininity is accentuated, as others appear to direct and maneuver Katniss' behaviours without her explicit consent or knowledge. Haymitch and Peeta cultivate the citizens' sympathies by exploiting Peeta's romantic feelings for her, thus normalizing her character within the context of a heterosexual romance and compulsory heterosexuality. Peeta again plays upon the citizens' sentiments through the media when he (falsely) announces that Katniss is pregnant prior to their participation in the Quell ( $75^{\text {th }}$ Hunger Games), thereby reinforcing the concept that she is a desirable, but vulnerable, woman who requires protection. "Even the most Capitol-loving, Games-hungry, bloodthirsty person out there can't ignore, at least for a moment, how horrific the whole thing is" (Catching Fire, p. 256). In the Games, Katniss' survival is positioned as requiring an acquiescence to emphasized femininity which is taken to an extreme when Peeta tells the Capitol viewers that Katniss is pregnant.

President Snow and Coin manipulate and control Katniss continually through threats and deception, attempting to use her as a pawn for their individual purposes. The rebellion leaders use Katniss as an unknowing symbol 
(mockingjay) and figurehead. Only relatively late in the trilogy does Katniss make a conscious decision to embrace this role, recognizing the power associated with the position. "I was their Mockingjay long before I accepted the role... I have a kind of power of I never knew I possessed" (Mockingjay, pp. 90-91). She also asserts greater self-determinism and control over her behavior at this point in ways similar to the Katniss from the beginning of the trilogy, enacting her own agency in resistance to the plans that others hold for her. For example, when informed that their mission to the Capitol would be a largely staged one intended to inspire viewers, with "'as many young and attractive victors as possible"' (Mockingjay, p. 254), Katniss seemingly complies while simultaneously devising a secret mission with "no intention of staying with the 'Star Squad'" (Mockingjay, p. 257).

Katniss views herself as unworthy of Peeta throughout most of the second and third books. Despite her vow to "Keep Peeta alive" (Catching Fire, p. 189, italics in original) as her "dying wish" (Catching Fire, p. 189), she agrees with Haymitch when he states, "'You could live a hundred lifetimes and not deserve him [Peeta], you know'" (Catching Fire, p. 178). When Peeta is captured by the Capitol and brainwashed into hating Katniss, his hate is portrayed as out of his control and as something that he courageously works to overcome. Katniss, however, responds by pushing Peeta away, worrying that "Finally, he can see me for who I truly am. Violent. Distrustful. Manipulative. Deadly. And I hate him for it" (Mockingjay, p. 232). Haymitch chastises her for her unwillingness to stand by Peeta, stating that, if their roles were reversed, Peeta would assist her.

"If you'd been taken by the Capitol, and hijacked, and then tried to kill Peeta, is this the way he would be treating you?" demands Haymitch.

I fall silent...He would be trying to get me back at any cost. Not shutting me out, abandoning me, greeting me with hostility at every turn.

"You and me made a deal to try and save him. Remember?.... Try and remember." (Mockingjay, p. 269).

In the social world of the Games and Panem, Katniss continually questions herself, alternately feeling more and less worthy in comparison to others. As Hayes and Flannery (2000) argue, "women's identity and self-esteem are intertwined with learning, unlearning, and relearning who we are and how to value ourselves" (p. 78). However, this learning is not individualized, but is connected to Katniss' context and the challenges she faces. She typically values Peeta over herself, deeming him more admirable. Even though Peeta is portrayed as encompassing marginalized masculinity, this positioning is represented as superior to a strong woman who is tethered to emphasized femininity, reinforcing a hierarchy of patriarchal power.

Katniss momentarily rejects this patriarchal power, which is systemically present in society and individually personified in Presidents Snow and Coin, by killing Coin instead of Snow (who was slated for execution). This is Katniss' first decision to harm another person intentionally and not in some form of defense (unlike Gale, who has long since accepted death as necessary). Her actions are spurred by Coin's support for having children from the Capitol participate in one last Hunger Games and her desire to avoid establishing another brutal and violent dictatorship. It is in this act of violence that Katniss is represented as a decisive individual who opposes violence (ironically, through a violent act) and recognizes that others have manipulated her to serve their interests. Katniss gives up at this point, resolving to waste away into nothingness.

They can fatten me up. They can give me a full body polish, dress me up, and make me beautiful again. They can design dream weapons that come to life in my hands, but they will never again brainwash me into the necessity of using them (Mockingjay, p. 377).

Her life is saved when Haymitch takes her home to the remains of District 12, where she eventually settles with Peeta.

Throughout the series, Katniss expresses uncertainty about her feelings towards Peeta and Gale. She is unable to choose one over the other (or make a decision to be with neither) until after the rebellion. Her ultimate decision to remain with Peeta is presented as a default and self-serving one, with Gale predicting that Katniss will make the decision to "pick whoever she thinks she can't survive without" (Mockingjay, p. 329), not who she loves. Her confusion is not viewed as understandable given the difficult circumstances of her life, nor is the possibility that she might be in love with both or neither of them considered acceptable. Instead, she is presented as a girl who cannot make up her mind. In the end, Katniss describes how she is drawn not to "Gale's fire, kindled with rage and hatred" as she has "plenty of fire myself" (Mockingjay p. 388) but to "the promise that life can go on, no matter how bad our losses. That it can be good again. And only Peeta can give me that" (Mockingjay, p. 388).

In the epilogue, Katniss describes herself as a reluctant mother who is fearful of the future (reminiscent of her own mother). She has children at Peeta's insistence, "it took five, ten, fifteen years for me to agree. But Peeta 
wanted them so badly" (Mockingjay, p. 389). In her life, she had been a hunter and provider, a tribute, a victor, a symbol of hope as a rebel, and an assassin. And yet, the book ends with her becoming a somewhat passive mother in an isolated community defined by her domestic role in a heteronormative family, tying her back to her nurturing relationships with Prim and Rue.

Katniss is arguably the character most conflicted by societal norms associated with her gender. Prior to the Hunger Games and outside of the watchful eyes of the Capitol and media, Katniss' views herself in positive ways. She is an unflawed young woman who is not only strong, independent, and able to survive under the most difficult of circumstances, but she is a compassionate caregiver to her sister. It is only when Katniss is subjected to the Hunger Games, and the corresponding scrutiny of the media, that she must change her appearance and behaviours. The characteristics of distrust, aggression, and caution, which are inconsistent with emphasized femininity and more consistent with hegemonic masculinity, are portrayed as negative attributes as opposed to necessary survival skills in a dangerous treacherous environment. In order to gain audience approval and sponsorship, she needs to adopt a feminine, romantic orientation as the object of heterosexual desire. It is within this role that Katniss is most imperfect - she struggles against traditional feminine expectations while simultaneously refusing to participate in hegemonically masculine acts of violence.

Instead of recognizing her decisions as necessary for survival, she is often self-critical and self-loathing. The Games of the Capitol forced her to question her identity and her actions; in the context of the Games and the rebellion, she is neither sufficiently feminine nor masculine and, thus, appears flawed. The story is informed by the contradictory nature of the main character's voice (Bacchilega 1997), with Katniss unsure of her own strengths and the complex nature of the positions to which she is forced. She therefore remains caught in a system that rewards forms of emphasized femininity and is "saved" when she returns "to her proper sexual role" (Dominguez-Rue, 2010, p. 306) by giving birth to Peeta's children and returning to the home.

\section{Implications}

The ways in which the characters of Katniss, Gale, and Peeta are represented through Katniss' voice in The Hunger Games trilogy demonstrates the gendered nature of not only the series, but of children's and young adult literature and Western society. Overall, Gale and Peeta are set up as performing somewhat competing discourses of masculinity, hegemonic versus marginalized, a relative juxtaposition that positions Katniss as a complex amalgamation of masculinity and femininity. Equally interesting are the ways in which each character's discourse of gender interacts with the others. If, as Connell (2005) states, "Masculinity and femininity are inherently relational concepts, which have meaning in relation to each other, as a social demarcation and a cultural opposition" (p. 43), then the continual contrast of Gale with Peeta is particularly telling, as are the ways in which Katniss enacts aspects of hegemonic masculinity and emphasized femininity.

The contradictory ways in which Katniss is represented, as heroic and yet a sexual object subservient to male norms, is similar to Hager's (2008) discussion of the cartoon Powerpuff Girls, who states, "the challenges faced by these superheroic animated girls frame current competing and often contradictory discourses about twentieth-century American girlhood in popular culture, revealing the transformational and yet deeply conservative character of American ideals of feminine strength, sexuality, and agency" (p. 62). However, Katniss's disdain for being required to conform to patriarchal norms of female beauty can be perceived as an invitation to the reader, "to question the necessity of those rules and the patriarchal State that enforces them" (Hager, 2008, p. 73).

While there are selected instances in literature, including The Hunger Games, where women and girls are presented as "alternative versions of the feminine" (Pérez Valverde, 2009, p. 272), with primary characters challenging societal norms and demonstrating independence, there is a need to problematize their eventual "retreat to the domestic sphere" (p. 272). For example, the "heteronormative attraction" (Pugh \& Wallace 2008, p. 190) found between male and female characters in the Harry Potter series are analogous to that between Katniss and Peeta/Gale. While the Harry Potter "epilogue pays homage to bourgeois parenting with its cheerful accounting of nuclear families" (Pugh \& Wallace, 2008, p. 190), The Hunger Games' epilogue pays homage to parenting in exile with its dystopian accounting of nuclear families. Men and women are portrayed as engaging in heteronormative relationships regardless of the setting, with the nuclear family and domesticity being the desired ending.

We agree with Baecker (2007) that characters "lose something of themselves in order to enjoy security within the patriarchal construct of marriage. Clearly, rescue comes at a significant cost" (p. 199). Katniss describes that she needs Peeta "to survive" (Mockingjay, p. 388) and that she is rescued by his love and acceptance. However, conforming to the roles of lover and mother work to restrict her to the domestic sphere and eclipse her roles as 
protector and rebel. The Hunger Games trilogy, despite ostensibly representing Katniss as strong, independent and, in need of no man, returns to mirror "the traditional tales [that] do equate feminine power with being unwomanly if not inhuman. They tell us that it is not natural for a woman to be active or powerful" (Parsons, 2004, p. 138). What is demonstrated as "natural," or perhaps more accurately, inevitable, is Katniss' eventual submission to a heteronormative order that positions women as belonging to the home, even though Katniss resists it.

We argue that The Hunger Games trilogy's critique of systemic power, violence, and media influence is strong and compelling. The ways in which gender is explored, however, is more nuanced. Katniss' critical assessment of the demands that are put upon her with respect to her appearance and the need for heteronormative romance demonstrates their unreasonableness and, often, perverseness. However, her continual self-talk and questioning of her own actions presents her as indecisive as well as selfish, particularly as compared to Peeta. Interestingly, the character who is viewed as the most worthy by Katniss appears to be Peeta who, while initially representing a position of marginalized masculinity, eventually enacts a more hegemonic one, with masculinity yet again securing "the dominant positions of men and the subordination of women" (Connell, 2005, p. 77).

While the "heterosexual, romantic storylines incorporated in most fairy tales [and other types of fiction] is so much a part of our being-in-the-world that it is extremely difficult to read and write outside it" (Parsons, 2004, p. 141), it is, nonetheless, interesting that The Hunger Games trilogy adopted relatively conventional notions of heteronormativity, particularly in its ending. However, there are "limitations of otherwise progressive texts" (Chaudhri, 2011, p. 160) and readers also have expressed disappointment over female characters who do not marry (Puleo, 2009, p. 374), which perhaps influences authors' plot decisions. Regardless, as Parsons et al (2008) discuss with reference to Gaiman's postfeminist fairy tales, "defiance of conventions is worthy of celebration, but it is therefore equally worthy of critique" (p. 372).

We have therefore engaged in an analysis, with respect to the characters' representations of hegemonic masculinity, marginalized masculinity, and emphasized femininity, that questions whether they could have been portrayed differently while maintaining the integrity of the narrative. Could Gale have rejected violence but still obtained his objectives? Could Peeta's portrayal of marginalized masculinity been viewed as more of a strength throughout the series, as opposed to at the end when it became more hegemonic? Could Katniss have been provided the opportunity to question and resist the need to participate in a heteronormative romance without viewing herself as lacking or uncertain? What alternatives exist for the epilogue where Katniss assumes her final role as caregiver and mother? Could Katniss have been presented as a "strong" mother, returning to the competent and independent Katniss presented in the first novel? These questions continue with Tolmie's (2006) line of thought, asking, "is the insertion of feminist disapproval into familiar situations in some respects a cheap alternative, in terms of imaginative expense, to the much more difficult and unusual creation of alternative fantasies, or radically new or revolutionary fantasy?" (p. 155). What else might the series have been able to do to critique patriarchy and heteronormative ideals? How might this be done when individuals are "culturally cued to exaggerate" (Connell, 2005, p. 21) sex and gender differences? As reading is a "political activity, through which certain meanings and values (including patriarchal or masculinist ideas about gender) are propagated and established as socially correct or normative" (Cranny-Francis et al, 2003, p. 119), readers must continue to problematize gendered representations in fiction.

\section{References}

Bacchilega, C. (1997). Postmodern fairy tales: Gender and narrative strategies. Philadelphia: University of Pennsylvania Press.

Baecker, D. L. (2007). Surviving rescue: A feminist reading of Scott O'Dell's Island of the Blue Dolphins. Children's Literature in Education, 38(3), 195-206. http://dx.doi.org/10.1007/s10583-006-9030-4

Baker-Sperry, L., \& Grauerholz, L. (2003). The pervasiveness and persistence of the feminine beauty ideal in children’s fairy tales. Gender \& Society, 15(5), 711-726. http://dx.doi.org/10.1177/0891243203255605

Bird, A. M. (1998). Women behaving badly: Dahl's witches meet the women of the eighties. Children's Literature in Education, 29(3), 119-129. http://dx.doi.org/10.1023/A:1022445204446

Chaudhri, A. (2011). "Straighten up and fly right": Heteromasculinity in The Watsons Go to Birmingham - 1963. Children's Literature Association Quarterly, 36(2), 147-163. http://dx.doi.org/10.1353/chq.2011.0019

Collins, S. (2008). The Hunger Games. New York: Scholastic Press.

Collins, S. (2009). Catching Fire. New York: Scholastic Press. 
Collins, S. (2010). Mockingjay. New York: Scholastic Press.

Connell, R.W. (1987). Gender and power. Sydney: Allen and Unwin.

Connell, R. W. (2005). Masculinities (2nd ed.). Berkeley: University of California Press.

Connell, R. (2012). Gender: In world perspective (2nd ed.). Cambridge: Polity Press.

Connell, R. W., \& Messerschmidt, J. W. (2005). Hegemonic masculinity: Rethinking the concept. Gender \& Society, 19(6), 829-859. http://dx.doi.org/10.1177/0891243205278639

Cranny-Francis, A., Waring, W., Stavropoulos, P., \& Kirkby, J. (2003). Gender studies: Terms and debates. Houndsmills: Palgrave Macmillan.

Diekman, A. B., \& Murnen, S. K. (2004). Learning to be little women and little men: The inequitable gender equality of nonsexist children's literature. Sex Roles, 50(5/6), 373-85. http://dx.doi.org/10.1023/B:SERS.0000018892.26527.ea

Dominguez-Rue, E. (2010). Sins of the flesh: anorexia, eroticism and the female vampire in Bram Stoker's Dracula. Journal of Gender Studies, 19(3), 297-308. http://dx.doi.org/10.1080/09589236.2010.494346

Gee, J. P. (2005). An introduction to discourse analysis: Theory and method (2nd ed.). New York: Routledge.

Glaser, B. G., \& Strauss, A. L. (1967). The discovery of grounded theory. Chicago: Aldine.

Hager, L. (2008). "Saving the world before bedtime": The Powerpuff Girls, citizenship, and the little girl $\begin{array}{llll}\text { superhero. } \quad \text { Children's Literature Association } & \text { Quarterly, }\end{array}$ http://dx.doi.org/10.1353/chq.2008.0006

Haase, D. (Ed.). (2004). Fairy tales and feminism: New approaches. Detroit: Wayne State University Press.

Harries, E. W. (2001). Twice upon a time: Women writers and the history of the fairy tale. Princeton: Princeton University Press.

Hayes, E., \& Flannery, D. (2000). Women as learners: The significance of gender in adult learning. San Francisco: Jossey-Bass Publishers.

Heinecken, D. (2011). Haunting masculinity and frightening femininity: the novels of John Bellairs. Children's Literature in Education, 42(2), 118-131. http://dx.doi.org/10.1007/s10583-010-9127-7

Hockey, J. (2003). No more heroes: Masculinity in the infantry. In P. Higate (ed.), Military masculinities: Identity and the state (pp. 15-25). Westport: Praeger Publishers.

Jackson, S., \& Susan G. (2005). "Look Janet," "No you look John": Constructions of gender in early school reader illustrations across 50 years." Gender \& Education, 17(2), 115-28. http://dx.doi.org/10.1080/0954025042000301410

Lazar, M. M. (2005). Politicizing gender in discourse: Feminist CDA as political perspective and praxis. In Feminist critical discourse analysis, ed. M.M. Lazar, 1-28. London: Palgrave Macmillan.

McInally, K. (2008). Who wears the pants? The (multi)cultural politics of The Sisterhood of the Traveling Pants. Children's Literature in Education, 39, 187-200. http://dx.doi.org/10.1007/s10583-008-9068-6

Messner, M. (2007). The masculinity of the governator: Muscle and compassion in American politics. Gender \& Society, 21(4), 461-480. http://dx.doi.org/10.1177/0891243207303166

Parsons, E., Sawers, N., \& McInally, K. (2008). The other mother: Neil Gaiman's postfeminist fairytales. Children's Literature Association Quarterly, 33(4), 371-89. http://dx.doi.org/10.1353/chq.0.1873

Parsons, L. T. (2004). Ella evolving: Cinderella stories and the construction of gender-appropriate behavior. $\begin{array}{llll}\text { Children's Literature } & \text { in }\end{array}$ http://dx.doi.org/10.1023/B:CLID.0000030223.88357.e8

Pattee, A. S. (2008). Sexual fantasy: The queer utopia of David Levithan's Boy Meets Boy. Children's Literature Association Quarterly, 33(2), 156-171. http://dx.doi.org/10.1023/B:CLID.0000030223.88357.e8

Pérez Valverde, C. (2009). Magic Women on the Margins: Ec-centric Models in Mary Poppins and Ms Wiz. Children's Literature in Education, 40(4), 263-274. http://dx.doi.org/10.1007/s10583-009-9090-3

Pugh, T, \& Wallace, D. L. (2008). A postscript to "Heteronormative heroism and queering the school story in J.K. Rowling's Harry Potter series." Children's Literature Association Quarterly, 33(2), 188-192. http://dx.doi.org/10.1353/chq.0.0009 
Puleo, R. (2009). Rebecca's revision: Expectations of the girl's novel and Kate Douglas Wiggin's Rebecca of Sunnybrook Farm and New Chronicles of Rebecca. Children's Literature Association Quarterly, 34(4), 353-378. http://dx.doi.org/10.1353/chq.0.1934

Taber, N., \& Woloshyn, V. E., (2011a). Dumb dorky girls and stinky wimpy boys: Gendered themes in diary cartoon novels. Children's Literature in Education, 42(3), 226-242. http://dx.doi.org/10.1007/s10583-011-9131-6

Taber, N., \& Woloshyn, V. E., (2011b). Issues of exceptionality, gender, and power: Exploring Canadian children's award-winning literature. Gender and Education, 23(7), 889-902. http://dx.doi.org/10.1080/09540253.2010.549112

Tolmie, J. (2006). Medievalism and the fantasy heroine. Journal of Gender Studies, 15(2), 145-158. http://dx.doi.org/10.1080/09589230600720042

Trousdale, A. M., \& McMillan, S. (2003). "Cinderella was a wuss": A young girl's responses to feminist and patriarchal folktales. Children's Literature in Education, 34(1), 1-28. http://dx.doi.org/10.1023/A:1022503415519

Waller, A. (2004). "Solid all the way through": Margaret Mahy's Ordinary Witches. Children's Literature in Education, 35(1), 77-86. http://dx.doi.org/10.1023/B:CLID.0000018902.40058.f3

Wannamaker, A. (2006). Reading in the gaps and lacks: (De)constructing masculinity in Louis Sachar's Holes. Children's Literature in Education, 37(1), 15-33. http://dx.doi.org/10.1007/s10583-005-9452-4

Wolf, N. (2002). The beauty myth: How images of beauty are used against women. New York: Harper Perennial.

\section{(cc) EY}

This work is licensed under a Creative Commons Attribution 3.0 License. 